\title{
Novel Classification of Posttraumatic Ear Deformities and its Surgical Management
}

\author{
Umesh Kumar $^{1}$ P. Jain ${ }^{1}$ \\ ${ }^{1}$ Department Plastic Surgery, Institute of Medical Sciences, Banaras \\ Hindu University, Varanasi, Uttar Pradesh, India
}

Address for correspondence Umesh Kumar, MD, 25 Brij enclave Extension-1, PO-Bazardiha, Varanasi, Uttar Pradesh, 221 109, India (e-mail: umeshkrplastic@gmail.com).

Indian J Plast Surg:2020;53:280-286

\begin{abstract}
Keywords

- traumatic ear deformity

- zone of defect

- post auricular skin

- temporoparietal fascia flap

Background Classification of posttraumatic ear deformities and its reconstruction is an uphill task for a reconstructive surgeon as they present in various combinations. In our study, we have described ear deformity as per a new classification and reconstructed the ear accordingly.

Method Posttraumatic ear deformity was described under the following four headings: (a) zone of defect, (b) size of defect, (c) missing components, and (d) condition of surrounding skin. Twenty-six posttraumatic ear deformities were operated using postauricular skin flap (14), temporoparietal fascial (TPF) flaps (8), preauricular skin flap (1), intralesional excision (2), and primary closure with chondrocutaneous advancement in one patient. Costal cartilage was used for reconstruction of framework wherever required. Framework elevation was done 4 to 6 months postoperatively. Results Posttraumatic ear deformity was more common in males. Bite injury and road traffic accidents were the common causes. Zones I, II and III were most frequently involved. Four patients complained about size, contour, and projection of reconstructed ear. Three patients were not satisfied by the appearance of junction between reconstructed and residual ear. Four patients in whom the reconstruction was done with TPF, costal cartilage, and thin (SSG) split skin grafts complained of hyperpigmentation of reconstructed ear.

Conclusion Classification of posttraumatic ear deformity and its reconstruction is a surgical challenge. Unscarred postauricular skin and TPF flaps are the workhorse flaps for reconstruction of acquired ear deformities. Our classification helps in describing the defect, documenting it, planning reconstruction, and aiding in assessing postoperative outcomes.
\end{abstract}

\section{Introduction}

Ear being a complex three-dimensional (3D)elastic structure is very difficult to reconstruct because of lack of purchase of adjacent skin due to pre-existing meatus. ${ }^{1}$ The most popular anatomical classification of full-thickness defects of ear divides it into the following six categories: (1) defects of upper third, (2) middle third, (3) lower third, (4) partial loss, (5) total loss, and (6) loss of lobule. ${ }^{2}$

We hereby propose a new classification system for posttraumatic ear deformities on the basis of four subheadings: (a) Zone of defect; (b) Size of defect in centimeter; (c) Absent components; (d) Condition of the surrounding skin.

\section{Materials and Methods}

This study was conducted in the Department of Plastic Surgery from 2015 to 2019 in 26 patients with ear defects. We categorized the ear defects under four headings as mentioned above. A vertical line is drawn at the base of the ear. The ear is then divided into two halves by a horizontal line just above the external auditory meatus. Each half of the ear
License terms

(이 (1) $\Theta \circledast$ 
was further divided into two by an angular bisector at $45^{\circ}$ angles. Thus, the ear is divided into four zones. We numbered them as zone I, zone II, zone III and zone IV in craniocaudal direction. Defect involving each zone was measured in centimeters. Involved anatomical structures were described in abbreviation like helix (h), antihelix (ah), triangular fossa $(\Delta)$, crus helix (ch), cymba (cy), cavum (ca), scaphoid fossa $(\mathrm{sc})$, tragus (t), antitragus (at), lobule (l), and external auditory meatus (eam). The fourth heading describes condition of pre- and postauricular skin and we documented it as scarred or unscarred ( - Fig. $\mathbf{1}$ ).

The age of the patients ranged from 9 to 56 years (male:female $=1.4: 1$ ). It was caused by road traffic accidents (6), bite injury (9; human 7 and animal 2), following injection of sodium tetradecyl sulfate (1), assault (2), postpiercing keloid excision (2), postburn deformity (2), postotoplasty (1), infection (1), fall from height (1) and glass cut injury (1).

In 21 patients, the postauricular skin was normal and in five it was scarred. Posttraumatic ear deformity involved single zone in eight patients. In 18 patients, the defect involved two or more zones in various combinations with frequent involvement of upper three zones (-Table 1). Postauricular flap was used for reconstruction in 14 patients, Temporoparietal fascia (TPF) flap with split skin graft (SSG) was used in eight patients, preauricular flap (1), intralesional excision was done in two patients, and in one patient, freshening of margins was done with chondrocutaneous advancement and primary closure. Ear reconstruction was done in one stage (12) and two-stage surgery was done in 14 patients ( - Table 2 ). Contralateral costal cartilage was used in cases where support was required, it harvested from 6th and 7th costal cartilage synchondrosis, and for helix reconstruction from the 8th costal cartilage. Twelve French suction drains were used beneath the skin flap, and in the

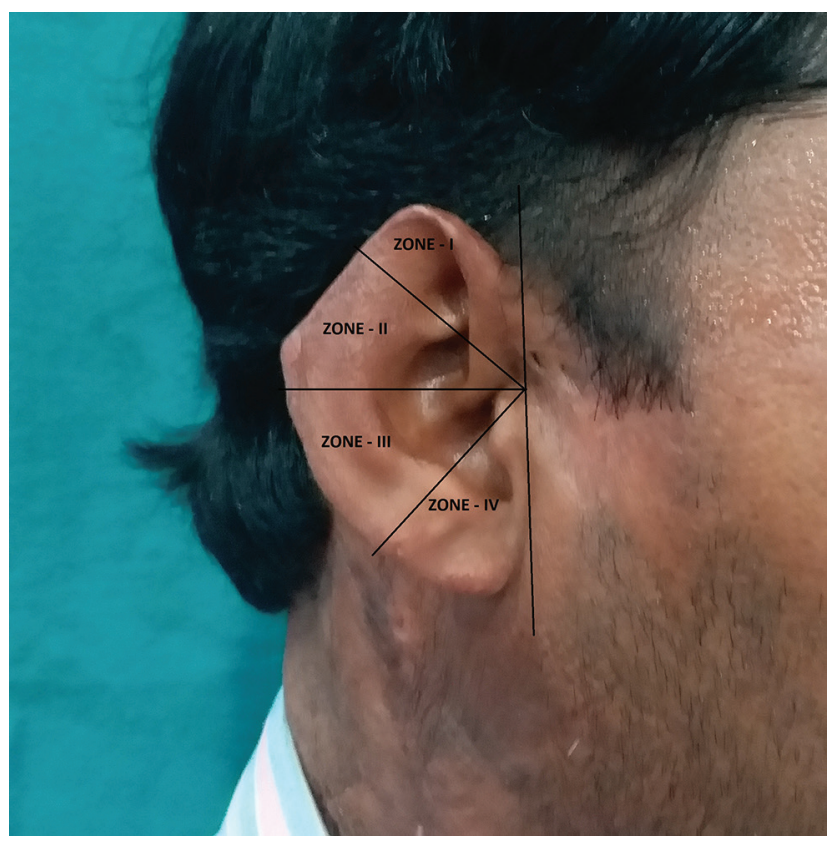

Fig. 1 (A) Defect involving zone-I and II, (B) size $2 \mathrm{~cm},($ C) involved anatomical structure helix (h), and (D) scarred postauricular skin. chest, it was removed from the 5th to 7th postoperative day. In two-stage procedure, with posteriorly buried ear framework, it was elevated 4 to 6 months later. When a superiorly, inferiorly or advancement-based postauricular flap was used, second stage surgery was done after 3 to 4 weeks.

\section{Case Report 1}

A 36-year-old female suffering from vascular malformation involving postauricular sulcus and adjoining skin was administered intralesional injection of sodium tetradecyl sulfate $(1 \mathrm{~mL})$. After three cycles of therapy, she presented with blackening and hardening of skin involving zones II and III. Surgical debridement and simultaneous one-stage ear reconstruction was done with costal cartilage graft harvested from 6th costal cartilage and ipsilateral TPF flap with thin split thickness skin graft. The small loss of skin graft from lateral surface was managed conservatively with dressings and oral antibiotic. Healing was achieved after 3 weeks ( - Fig. 2).

\section{Results}

Acquired ear deformity was more common in males (15:11). The most common cause of injury was bite injury followed by road traffic accidents. In 14 patients, the postauricular skin was unscarred and was used for reconstruction of the ear in two stages. The commonest site of injury was the upper three zones. Four patients complained regarding size, contour, and projection of the ear framework. In three patients, there was junctional groove between the reconstructed ear and the residual ear. Two of our patients had framework exposure, following color change in the skin. It was managed conservatively. Complaints regarding hyperpigmentation and color difference from adjacent skin was lodged by four patients who underwent single stage reconstruction with TPF flap and thin SSG. Hair loss approximately of half centimeter size was present at TPF flap donor site in one patient. In two cases, hairline was low, which resulted in transfer of hair-bearing skin on the reconstructed ear and managed postoperatively by laser therapy. The aesthetic outcome was good in patients where the defect was confined to one zone and was satisfactory where the defect involved more than two or three zones.

\section{Discussion}

The skin posterior to the ear is scarred in quite a good number of trauma cases which restricts creation of a skin pocket during ear reconstruction. Low-hairline in younger population also causes transfer of hair-bearing skin to the reconstructed ear.

Patient's expectations are very high, and this injury has a psychological component. In general, the most common cause of traumatic amputation of ear is (a) road traffic accidents, (b) bite injuries, (c) burns, (d) lacerations, (e) iatrogenic, and (f) infections.

Posttraumatic ear deformity may be the only injury sustained by an individual, or it may be associated with life-threatening emergencies. The biggest difficulty is in the 
Table 1 Details of patients with etiology, involved zones, treatment and complications

\begin{tabular}{|c|c|c|c|c|c|c|c|c|c|c|}
\hline $\begin{array}{l}\text { Sl. } \\
\text { No }\end{array}$ & $\begin{array}{l}\text { Age, } \\
\text { sex }\end{array}$ & Etiology & $\begin{array}{l}\text { Anatomical } \\
\text { region }\end{array}$ & $\begin{array}{l}\text { Involved } \\
\text { zones }\end{array}$ & $\begin{array}{l}\text { Size of } \\
\text { defect } \\
\text { in } \mathrm{cm}\end{array}$ & $\begin{array}{l}\text { Absent } \\
\text { anatomical } \\
\text { structure }\end{array}$ & $\begin{array}{l}\text { Condition } \\
\text { of post- } \\
\text { operative } \\
\text { skin }\end{array}$ & Treatment & $\begin{array}{l}\text { Number } \\
\text { of stages }\end{array}$ & Complication \\
\hline 1. & $32, \mathrm{M}$ & RTA & Upper third & $\begin{array}{l}\text { Zones I } \\
\text { and II }\end{array}$ & 3 & ch, h, ah, sc & scarred & $\begin{array}{l}\text { Postauricular skin, } \\
\text { costal cartilage } \\
\text { and SSG }\end{array}$ & 2 & None \\
\hline 2. & $36, F$ & $\begin{array}{l}\text { Postsodium } \\
\text { tetradecyl } \\
\text { sulfate } \\
\text { injection in } \\
\text { arteriovenous } \\
\text { malformation }\end{array}$ & $\begin{array}{l}\text { Upper middle } \\
\text { third }\end{array}$ & $\begin{array}{l}\text { Zones II } \\
\text { and III, }\end{array}$ & 4 & h, ah, sc & Normal & $\begin{array}{l}\text { TPF flap, costal } \\
\text { cartilage graft and } \\
\text { SSG }\end{array}$ & 1 & Exposed cartilage \\
\hline 3. & $24, M$ & RTA & $\begin{array}{l}\text { Upper middle } \\
\text { third }\end{array}$ & $\begin{array}{l}\text { Zones I, II } \\
\text { and III }\end{array}$ & 5 & $\begin{array}{l}\text { h, ah, sc, cy, } \\
\text { ca, ch, } \Delta\end{array}$ & Scarred & $\begin{array}{l}\text { TPF flap, costal } \\
\text { cartilage graft and } \\
\text { SSG }\end{array}$ & 1 & Hyperpigmentation \\
\hline 4. & $18, \mathrm{~F}$ & Bite injury & $\begin{array}{l}\text { Upper, middle } \\
\text { and lower } \\
\text { third }\end{array}$ & $\begin{array}{l}\text { Zones I, II, } \\
\text { III and IV }\end{array}$ & 6 & $\begin{array}{l}\text { Lobule } \\
\text { present }\end{array}$ & $\begin{array}{l}\text { Normal } \\
\text { skin }\end{array}$ & $\begin{array}{l}\text { Postauricular skin } \\
\text { flap and costal } \\
\text { cartilage }\end{array}$ & 2 & $\begin{array}{l}\text { Unnatural appearing } \\
\text { junction }\end{array}$ \\
\hline 5. & $22, \mathrm{M}$ & $\begin{array}{l}\text { Assault with } \\
\text { sharp object }\end{array}$ & $\begin{array}{l}\text { Upper and } \\
\text { middle third }\end{array}$ & $\begin{array}{l}\text { Zones I, } \\
\text { II, III, }\end{array}$ & 4 & h, sc, ah, $\Delta$ & $\begin{array}{l}\text { Normal } \\
\text { skin }\end{array}$ & $\begin{array}{l}\text { TPF flap, costal } \\
\text { cartilage and SSG }\end{array}$ & 1 & Small size \\
\hline 6. & $20, M$ & $\begin{array}{l}\text { Postanimal } \\
\text { bite }\end{array}$ & Middle third & Zone III & 2 & $h, a h$ & $\begin{array}{l}\text { Normal } \\
\text { skin }\end{array}$ & $\begin{array}{l}\text { Postauricular skin } \\
\text { flap }\end{array}$ & 2 & Unnatural junction \\
\hline 7. & $47, M$ & Assault & $\begin{array}{l}\text { Upper and } \\
\text { middle third }\end{array}$ & $\begin{array}{l}\text { Zones II } \\
\text { and III }\end{array}$ & 3 & $\mathrm{~h}$ & Normal & $\begin{array}{l}\text { Postauricular skin } \\
\text { flap }\end{array}$ & 2 & None \\
\hline 8. & $21, M$ & $\begin{array}{l}\text { Laceration due } \\
\text { to fall }\end{array}$ & Upper third & Zone II & 1 & $\mathrm{~h}$ & Normal & $\begin{array}{l}\text { Chondrocutaneous } \\
\text { advancement } \\
\text { and suturing }\end{array}$ & 1 & None \\
\hline 9. & $18, \mathrm{M}$ & Bite injury & $\begin{array}{l}\text { Total loss of } \\
\text { ear }\end{array}$ & $\begin{array}{l}\text { Zones I, II, } \\
\text { III and IV }\end{array}$ & 6 & $\begin{array}{l}\text { All } \\
\text { structures } \\
\text { absent }\end{array}$ & Normal & $\begin{array}{l}\text { TPF flap and graft } \\
\text { over the ampu- } \\
\text { tated ear cartilage } \\
\text { after removal of } \\
\text { skin }\end{array}$ & 1 & $\begin{array}{l}\text { Loss of contour } \\
\text { of ear }\end{array}$ \\
\hline 10. & $24, \mathrm{M}$ & $\begin{array}{l}\text { Glass } \\
\text { laceration }\end{array}$ & $\begin{array}{l}\text { Upper third } \\
\text { of ear }\end{array}$ & $\begin{array}{l}\text { Zones I } \\
\text { and II }\end{array}$ & 3 & ch, h, ah, $\Delta$ & Normal & $\begin{array}{l}\text { Costal cartilage } \\
\text { and postauricular } \\
\text { skin }\end{array}$ & 2 & $\begin{array}{l}\text { Hair over recon- } \\
\text { structed ear }\end{array}$ \\
\hline 11. & $56, F$ & Bite injury & Lower & Zone IV & 1.5 & Lobule & Normal & Postauricular flap & 2 & None \\
\hline 12. & $9, \mathrm{~F}$ & $\begin{array}{l}\text { Post piercing } \\
\text { deformity }\end{array}$ & Lower third & Zone IV & 1.5 & Lobule & Normal & Intralesion excision & 1 & None \\
\hline 13. & $26, \mathrm{~F}$ & Bite injury & $\begin{array}{l}\text { Middle and } \\
\text { lower third }\end{array}$ & $\begin{array}{l}\text { Zones III } \\
\text { and IV }\end{array}$ & 3 & $\begin{array}{l}\text { h, ah, sc, at, } \\
\text { lobule }\end{array}$ & Normal & $\begin{array}{l}\text { Postauricular } \\
\text { flap with costal } \\
\text { cartilage }\end{array}$ & 2 & Unnatural junction \\
\hline 14. & $33, M$ & $\begin{array}{l}\text { Postpiercing } \\
\text { deformity }\end{array}$ & Lower third & Zone IV & 1.5 & Lobule & Normal & Intralesion excision & 1 & None \\
\hline 15. & $19, \mathrm{~F}$ & $\begin{array}{l}\text { Postotoplasty } \\
\text { deformity }\end{array}$ & Upper third & Zone II & 2 & h, ah, sc & Normal & TPF with SSG & 2 & Loss of projection \\
\hline 16. & $46, \mathrm{~F}$ & Bite injury & $\begin{array}{l}\text { Upper and } \\
\text { middle third }\end{array}$ & $\begin{array}{l}\text { Zones II } \\
\text { and III }\end{array}$ & 3 & h, ah, sc & Scarred & $\begin{array}{l}\text { Postauricular } \\
\text { flap and costal } \\
\text { cartilage }\end{array}$ & 2 & None \\
\hline 17. & $22, \mathrm{M}$ & $\begin{array}{l}\text { Postburn ear } \\
\text { deformity }\end{array}$ & $\begin{array}{l}\text { Upper, middle } \\
\text { and lower } \\
\text { third }\end{array}$ & $\begin{array}{l}\text { Zones II, } \\
\text { III and IV }\end{array}$ & 4 & $\begin{array}{l}\text { h, ah, sc, at, } \\
\text { lobule }\end{array}$ & $\begin{array}{l}\text { Scarred } \\
\text { lower third }\end{array}$ & $\begin{array}{l}\text { Costal cartilage } \\
\text { and post auricular } \\
\text { skin }\end{array}$ & 2 & Exposed cartilage \\
\hline
\end{tabular}

(continued)

description of the deformity and its documentation. In standard text, the defect is divided into six subheadings, but the injury pattern seen in some of our patients does not adhere to it.

Luo et al classified acquired ear deformities, depending upon the involved tissue components, size of defect, and status of surrounding soft tissue into 5 types, with different reconstruction modalities used for each type. The five types are as follows: Type I: severely cicatrical ear without cartilage deficit; Type II: partial full-thickness defects; Type III: most part of or total ear loss, periauricular skin intact; Type IV: most part or total ear loss, periauricular skin involved; Type V: most part or total loss of healthy surrounding skin and soft tissue involving TPF unavailability. ${ }^{3}$ Datao et al (2016) classified posttraumatic ear deformities into four types according to defect size and surrounding skin condition. The defects were classified, and reconstruction was done with either (a) auricular or costal cartilage 
Table 1 (Continued)

\begin{tabular}{|c|c|c|c|c|c|c|c|c|c|c|}
\hline $\begin{array}{l}\text { Sl. } \\
\text { No }\end{array}$ & $\begin{array}{l}\text { Age, } \\
\text { sex }\end{array}$ & Etiology & $\begin{array}{l}\text { Anatomical } \\
\text { region }\end{array}$ & $\begin{array}{l}\text { Involved } \\
\text { zones }\end{array}$ & $\begin{array}{l}\text { Size of } \\
\text { defect } \\
\text { in cm }\end{array}$ & $\begin{array}{l}\text { Absent } \\
\text { anatomical } \\
\text { structure }\end{array}$ & $\begin{array}{l}\text { Condition } \\
\text { of post- } \\
\text { operative } \\
\text { skin }\end{array}$ & Treatment & $\begin{array}{l}\text { Number } \\
\text { of stages }\end{array}$ & Complication \\
\hline 18. & 24, M & $\begin{array}{l}\text { Posttraumatic } \\
\text { ear deformity }\end{array}$ & $\begin{array}{l}\text { Upper and } \\
\text { middle third }\end{array}$ & $\begin{array}{l}\text { Zone I } \\
\text { and II }\end{array}$ & 3 & $\begin{array}{l}\text { ch, h, ah, } \Delta \text {, } \\
\text { and cy }\end{array}$ & Normal & $\begin{array}{l}\text { Post auricular } \\
\text { flap and costal } \\
\text { cartilage graft }\end{array}$ & 2 & $\begin{array}{l}\text { Unnatural junction } \\
\text { and hair over recon- } \\
\text { structed ear }\end{array}$ \\
\hline 19. & $21, \mathrm{~F}$ & Bite injury & Lobule & Zone IV & 2 & Lobule & Normal & Preauricular flap & 1 & None \\
\hline 20. & $41, \mathrm{~F}$ & $\begin{array}{l}\text { Post- RTA } \\
\text { blackening } \\
\text { of ear }\end{array}$ & Upper third & Zone I & 2.5 & ch, h, $\Delta$ & Normal & $\begin{array}{l}\text { TPF flap and costal } \\
\text { cartilage with SSG }\end{array}$ & 1 & Hyperpigmentation \\
\hline 21. & $27, \mathrm{~F}$ & $\begin{array}{l}\text { Postburn ear } \\
\text { deformity }\end{array}$ & $\begin{array}{l}\text { Upper, middle } \\
\text { and lower } \\
\text { third }\end{array}$ & $\begin{array}{l}\text { Zones I, II, } \\
\text { III, and IV }\end{array}$ & 4 & $\begin{array}{l}\text { h, ah, sc, at, } \\
\text { lobule }\end{array}$ & Scarred & $\begin{array}{l}\text { TPF and costal } \\
\text { cartilage with SSG }\end{array}$ & 1 & Hyperpigmentation \\
\hline 22. & $31, \mathrm{M}$ & $\begin{array}{l}\text { Postanimal } \\
\text { bite ear } \\
\text { deformity }\end{array}$ & Total loss & $\begin{array}{l}\text { Zones I, II, } \\
\text { III and IV }\end{array}$ & 6 & Total loss & $\begin{array}{l}\text { Normal } \\
\text { low-hair } \\
\text { line }\end{array}$ & $\begin{array}{l}\text { TPF flap and costal } \\
\text { cartilage with SSG }\end{array}$ & 1 & Hyperpigmentation \\
\hline 23. & 24, M & Post infection & $\begin{array}{l}\text { Upper, middle } \\
\text { third }\end{array}$ & $\begin{array}{l}\text { Zones I } \\
\text { and II }\end{array}$ & 3 & h, sc, ah, $\Delta$ & Normal & $\begin{array}{l}\text { Costal cartilage } \\
\text { and postauricular } \\
\text { flap }\end{array}$ & 2 & $\begin{array}{l}\text { Loss of anatomical } \\
\text { details }\end{array}$ \\
\hline 24. & $31, \mathrm{M}$ & Bite injury & Lower third & $\begin{array}{l}\text { Zones II } \\
\text { and III }\end{array}$ & 3 & h, ah, sc & Normal & Postauricular flap & 2 & None \\
\hline 25. & $36, \mathrm{M}$ & Post-RTA & $\begin{array}{l}\text { Middle and } \\
\text { lower third }\end{array}$ & $\begin{array}{l}\text { Zones II } \\
\text { and III }\end{array}$ & 3 & h, ah, sc, ca & Normal & $\begin{array}{l}\text { Postauricular } \\
\text { flap and Costal } \\
\text { cartilage }\end{array}$ & 2 & None \\
\hline 26. & $39, \mathrm{~F}$ & $\begin{array}{l}\text { Posttraumatic } \\
\text { deformity }\end{array}$ & $\begin{array}{l}\text { Lower third } \\
\text { with lobule }\end{array}$ & $\begin{array}{l}\text { Zones III } \\
\text { and IV }\end{array}$ & 2.5 & at, lobule & Normal & Postauricular flap & 2 & None \\
\hline
\end{tabular}

Abbreviations: $\Delta$-triangular fossa; ah, antihelix; at, antitragus; ca, cavum; ch, crus helix; cy, cymba; eam, external auditory meatus; h, helix; sc, scaphoid fossa; SSG, split thickness skin graft; t, tragus; TPF, temporoparietal fascia.

Table 2 Zone wise reconstruction options in post traumatic ear defect

\begin{tabular}{|l|l|}
\hline $\begin{array}{l}\text { Zone of } \\
\text { posttraumatic } \\
\text { ear deformity }\end{array}$ & Reconstruction options \\
\hline Zone I & $\begin{array}{l}\text { Minor defect-composite graft from contralateral } \\
\text { ear, helical advancement flap, preauricular flap. } \\
\text { Intermediate defect-banner flap, } \\
\text { chondrocutaneous flap, } \\
\text { Large defect-costal cartilage graft buried in } \\
\text { postauricular skin pocket in two stages. } \\
\text { Costal cartilage graft covered by } \\
\text { temporoparietal fascial flap and SSG }\end{array}$ \\
\hline Zone II & $\begin{array}{l}\text { Antia and Buchs technique. } \\
\text { Costal cartilage graft covered by adjacent skin } \\
\text { flap } \\
\text { Converse's tunnel procedure in two stages } \\
\text { Postauricular tube flap } \\
\text { Dieffenbach's technique } \\
\text { Costal cartilage graft covered by TPF flap and } \\
\text { SSG (when it involves zones II and III, or zones I, } \\
\text { Il and III) }\end{array}$ \\
\hline Zone III & $\begin{array}{l}\text { Costal cartilage graft resurfaced by adjacent } \\
\text { skin flap } \\
\text { Converse tunnel procedure in two stages } \\
\text { Postauricular tube flap } \\
\text { Advancement of post-auricular flap }\end{array}$ \\
\hline Zone IV & $\begin{array}{l}\text { Preauricular flap } \\
\text { Alanis method } \\
\text { Converse's two flap technique } \\
\text { Brent's reverse contoured flap } \\
\text { Limberg flap } \\
\text { Contralateral conchal cartilage buried in lobule } \\
\text { region as a two-stage procedure. Intralesional } \\
\text { excision. }\end{array}$ \\
\hline
\end{tabular}

Abbreviations: SSG, split skin graft; TFP, temporoparietal fascia. (b) single-stage or two-stage, and (c) utilizing postauricular unscarred skin or TPF flap. ${ }^{4}$

The anatomical classification gives a rough idea of location of defect but poses limitations regarding the determination of the procedure to be executed. The classification described by Luo et al and Datao et al is reconstruction-oriented with the disadvantage of being lengthy and cumbersome to apply clinically. Keeping all these factors in mind, we thought to classify acquired ear deformities, in order to overcome the descriptive difficulties of ear defect. We divided ear into four equal zones, each separated by a 45-degree angle. Each zone roughly measured between 2 to $2.5 \mathrm{~cm}$ in length. The defect is described by mentioning the lost anatomical features in their abbreviated form, with special mention of surrounding skin. This classification is applicable in emergency as well as in outpatient facility. It helps in planning ear reconstruction and documentation of ear defects in long-term studies.

Defect involving ear was reconstructed by Nagata's modification of Brent's technique.,5 Cartilage was harvested from 6th and 7th costal cartilage synchondrosis, and 8th costal cartilage was used for reconstruction of helix. Carving was performed in each case. Due to nonavailability of stainless-steel wire sutures, 4-0 polypropylene suture was used. The carved ear was inserted into a dissected pocket in the postauricular unscarred region. ${ }^{7}$ In cases where the postauricular skin was scarred, or patient had low-hairline, we covered the carved cartilage with TPF flap and thin SSG. 

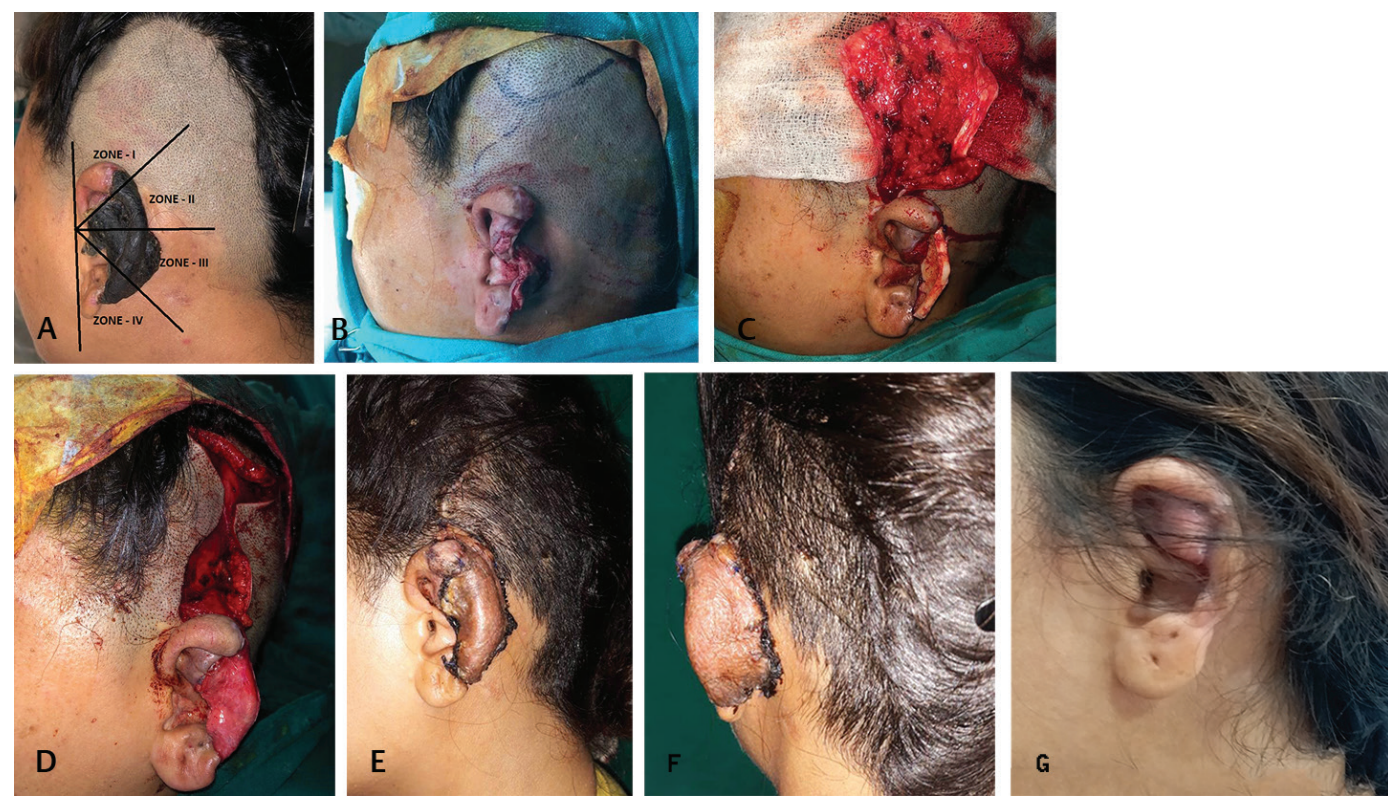

Fig. 2 Necrosis of ear involving zone-II and III. (A) Defect of zone-II and III. (B) Carved costal cartilage sutured into the defect (4 cm). (C) Cartilage resurfaced with temporoparietal fascia. (D) Postoperative result after SSG (lateral aspect). (E) Postoperative result after SSG (medial aspect). (F) Final result. Abbreviation: SSG, split skin graft.
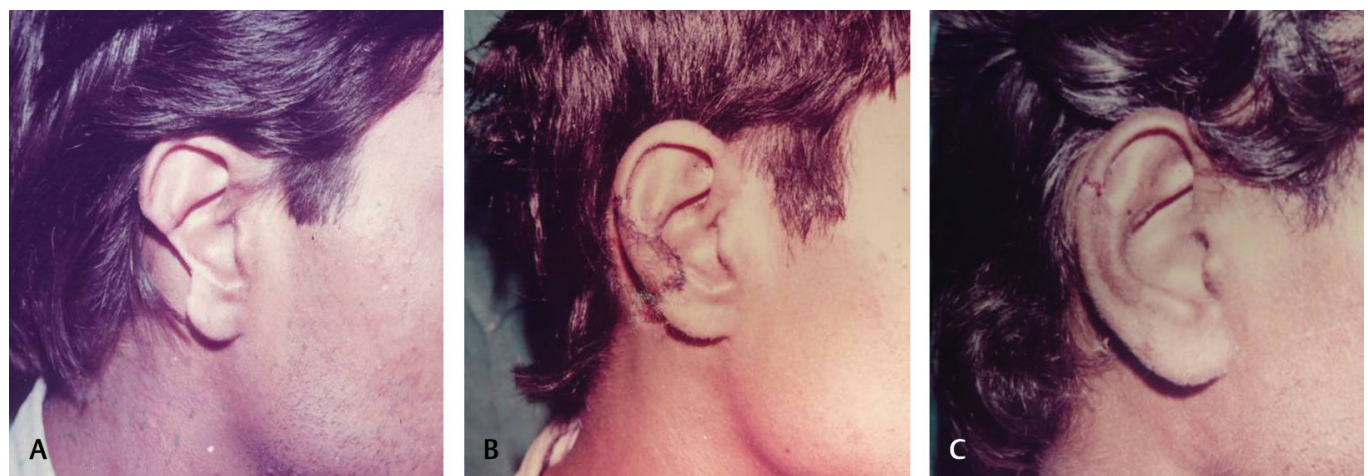

Fig. 3 (A) Defect involving zone-II and III, size $2 \mathrm{~cm}$, absent h, ah. (B) Early postoperative result following reconstruction with superiorly based postauricular flap and costal cartilage. (C) Late postoperative result with groove at junction of normal and reconstructed ear.

In our study, the upper half of the ear was most commonly involved. The upper half is the widest and most prominent part of the ear, thus making it prone to injury. As in our study, Kolodzynskin et al also found bite injury and road traffic accidents $(17 \%)$ to be the commonest cause, followed by burns (9.5\%) and postotoplasty $(9.5 \%)^{8}$

During reconstruction of defects involving zones I and II, with unscarred postauricular skin, we faced few challenges. The first challenge was tightness of the pocket, which always created a fear that it will lead to necrosis of skin and extrusion of the cartilage at the prominent anatomical landmarks. The second issue was the junction between the reconstructed ear and the normal ear. Residual ear helps in maintaining elevation of the ear but results in abnormally appearing junction between normal and reconstructed ear, and could have been avoided by using stainless-steel wire sutures. ${ }^{9}$ Datao et al (2016) in their study reported about this problem in two patients (one with type II and the other with type III defect). ${ }^{4}$ Four of our patients complained about abnormal ear contour, projection of ear, and ear size in comparison to the opposite ear. Ear projection was satisfactory in all patients where residual cartilage was present. The third problem was low-hairline, resulting in transfer of hair-bearing skin over reconstructed ear. This issue was managed postoperatively by laser therapy.

Partial ear defect over the periphery of the ear was mentioned in terms of the zone involved as well as the structure missing in the form of abbreviations. Helix loss was reconstructed by superiorly or inferiorly based postauricular flap in two stages. This procedure was done in two stages and the flap tubed on its own in 4 weeks to form the helix. In patients where the defect involved the helix as well as the antihelix, we used costal cartilage framework and buried it into postauricular skin flap, and the procedure was completed in two stages ( $\boldsymbol{- \text { Fig. }}$ 3). Small defects involving peripheral rim were managed by freshening of margins chondrocutaneous 
advancement and primary closure. The aesthetic outcome of these defects was excellent. Antia and Buchs procedure is an ideal technique for small peripheral defects using principle of $\mathrm{V}-\mathrm{Y}$ advancement of the skin and cartilage ${ }^{10}$ ( - Fig. 4).

In eight cases, TPF flap was used for reconstruction of defects involving zones I, II, III and IV ( - Fig. 5). In two cases, postauricular skin was scarred; in one patient, hairline was low, and in another patient, the lateral skin of ear was unhealthy with tissue loss, following sodium tetradecyl sulfate injection. The rest of our four patients had normal unscarred postauricular skin but opted for single-stage reconstruction without any postauricular scar. TPF flap is a thin, pliable, highly vascular tissue with reliably consistent blood supply. Hyperpigmentation of the reconstructed ear was one of the commonest complaints in the postoperative period. None of our patients complained of minor hair loss along the line of incision for harvesting TPF flap as it was camouflaged by adjacent hair. However, one has to be extremely cautious to avoid trauma to the roots of hair follicle by dissecting in subfollicular plane. Brent and Byrd (1983) stated that primary fascial flap may be considered if one predicts a tight cutaneous pocket, and if patient has low-hairline. ${ }^{11}$
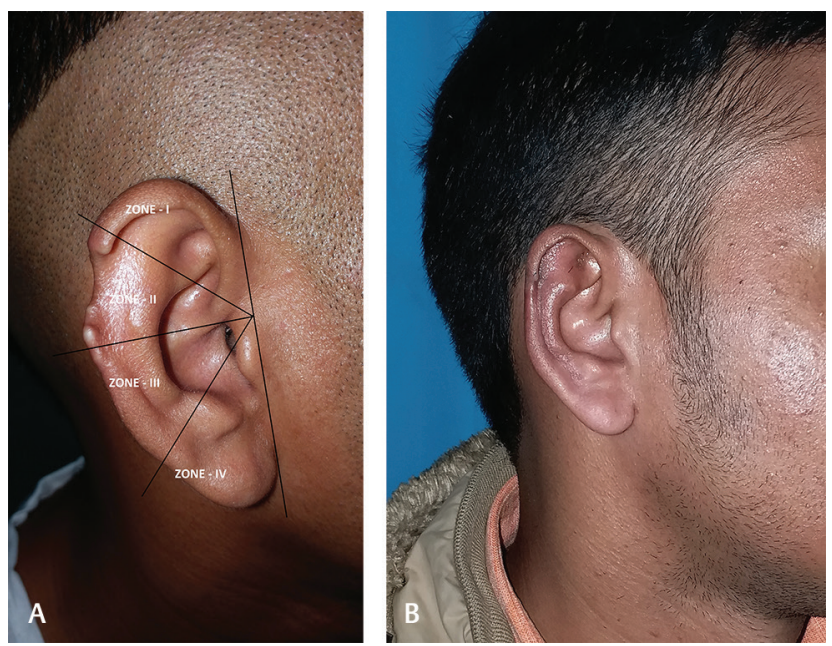

Fig. 4 (A) Defect involving zone-II with loss of helix, $1.5 \mathrm{~cm}$ in size with normal postauricular skin. (B) Postoperative result after chondrocutaneous advancement and suturing.
Isolated zone IV defect is very common, and no ear reconstruction is complete without it. Reconstruction of lobule is a challenge in total ear reconstruction where it can be done with the reconstructed costal cartilage. Where the lobule is lost, it can be reconstructed with flap from the postauricular or preauricular region or from both the regions combined..$^{12,13}$ In our study, two patients presented with lobule loss which was reconstructed with a preauricular and postauricular flap in single stage (-Fig. 6).

\section{Conclusion}

Posttraumatic ear deformities are difficult to classify as they present in various combinations. Classification and planning of reconstruction should be precise to meet the high-expectations of patients and their relatives. This classification helped in describing the defect in detail, documenting it in records, planning reconstruction, and evaluating reconstruction in the early and late postoperative periods.

\section{Declaration}

The study was approved by the Institutional Review Board. No clinical trial was performed during study.

\section{Source of Funding}

Nil.
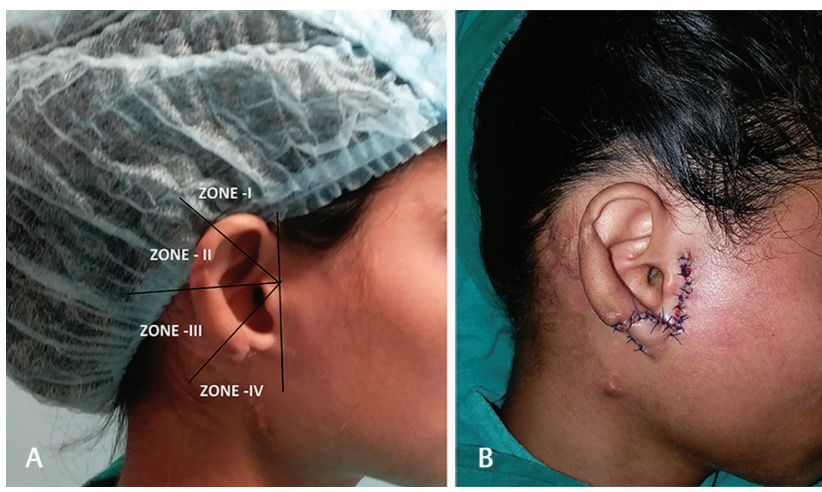

Fig. 6 (A) Defect involving zone-IV with absent lobule. (B) Early postoperative result after reconstruction with preauricular flap.
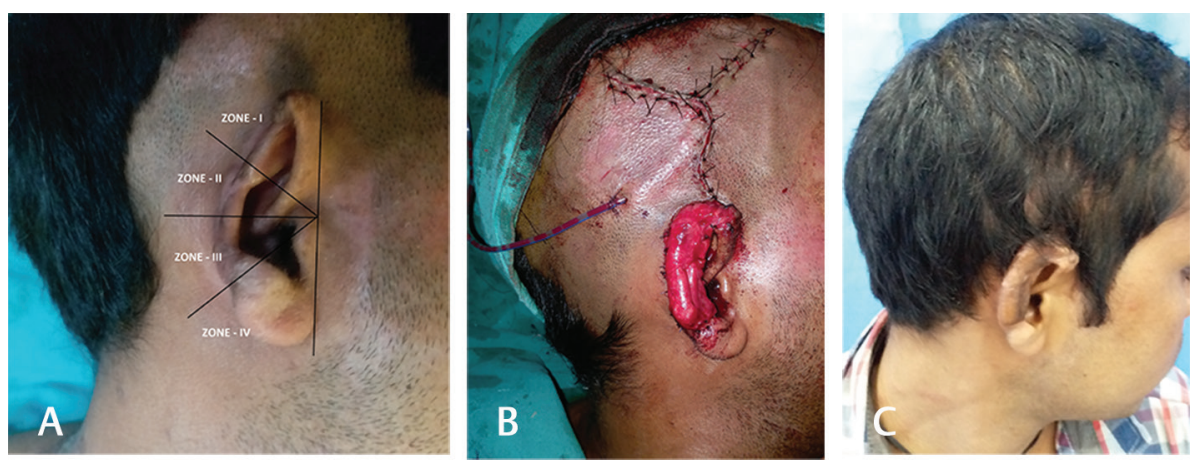

Fig. 5 (A) Defect involving zone-I, II and III with absent helix, scapha, and antihelix. Defect size $4 \mathrm{~cm}$ with low hairline. (B) Harvested temporoparietal fascial flap resurfaced over costal cartilage graft. (C) Late postoperative result. 


\section{Conflict of Interest}

Nil.

\section{References}

1 Brent BD, Reconstruction of ear. In: Neligan PC, ed. Plastic Surgery. 3rd ed. London: Elsevier Saunders; 2013 187-225

2 Brent B, Reconstruction of auricle. In: McCarthy JG, ed. Plastic Surgery. Philadelphia: W B Saunders; 1990 ;3:2094-2152

3 Luo X, Yang J, Yang Q, Wang X. Classification and reconstruction of posttraumatic ear deformity. J Craniofac Surg 2012;23(3):654-657

4 Li D, Xu F, Zhang R, et al. Surgical reconstruction of traumatic partial ear defects based on a novel classification of defect sizes and surrounding skin condition. Plast Reconstr Surg 2016;138(2):307e-316e

5 Brent B. The acquired auricular deformity. A systematic approach to its analysis and reconstruction. Plast Reconstr Surg 1977;59(4):475-485

6 Nagata S. A new method of total reconstruction of the auricle for microtia. Plast Reconstr Surg 1993;92(2):187-201
7 Schonauer F, Vuppalapati G, Marlino S, Santorelli A, Canta L, Molea G. Versatility of the posterior auricular flap in partial ear reconstruction. Plast Reconstr Surg 2010;126(4):1213-1221

8 Kolodzynski MN, Kon M, Egger S, Breugem CC. Mechanisms of ear trauma and reconstructive techniques in 105 consecutive patients. Eur Arch Otorhinolaryngol 2017;274(2):723-728

9 Sharma M, Dudipala RR, Mathew J, et al. Objective analysis of microtia reconstruction in Indian patients and modifications in management protocol. Indian J Plast Surg 2015;48(2):144-152

10 Antia NH, Buch VI. Chondrocutaneous advancement flap for the marginal defect of the ear. Plast Reconstr Surg 1967;39(5):472-477

11 Brent B, Byrd HS. Secondary ear reconstruction with cartilage grafts covered by axial, random, and free flaps of temporoparietal fascia. Plast Reconstr Surg 1983;72(2):141-152

12 Alconchel MD, Rodrigo J, Cimorra GA. A combined flap technique for earlobe reconstruction in one stage. Br J Plast Surg 1996;49(4):242-244

13 Singh A, Singh G. Earlobe reconstruction using a Limberg flap in six ears. Br J Plast Surg 2003;56(1):33-36 